\title{
COMMENTARY
}

\section{Another nail in the hammer's coffin?}

\author{
Mervyn Singer* and David Brealey \\ See related research by Shahin et al., http://ccforum.com/content/15/4/R162
}

\begin{abstract}
Blood pressure saggy? Cardiac output low? Oliguria? Increasing acidosis? Peripheries a bit cool? Poor cardiac history? No problem. Just start some dobutamine and watch the numbers improve. And if the patient happens to die, that is their fault. Or is it? Catecholamines are long-established drugs that have never undergone formal testing of long-term outcomes and safety. Their use requires re-evaluation in the light of a wide range of deleterious actions and retrospective studies suggesting harm.
\end{abstract}

In a carefully performed retrospective study of 1,314 patients undergoing cardiac surgery, Shahin and colleagues found that postoperative use of dobutamine was independently associated with a 2.3 -fold increase in mortality and a 2.7 -fold increased risk of renal dysfunction, after correcting for preoperative risk, cardiac function, intraoperative management and complications, and cardiac index [1]. A parallel greedy matching propensity analysis in 123 inotrope-exposed patients and 123 unexposed patients confirmed these findings [1]. This study builds upon that previously reported by Fellahi and colleagues in 657 cardiac surgical patients [2].

The decision to start an inotrope after cardiac surgery is often based on physician whim [3] and there is a general nonappreciation of harm. For many years we have displayed a blind devotion to catecholamines, aware but accepting of the occasional problems of tachycardia, arrhythmia and dusky digits. Like furosemide, oxygen, aspirin, digoxin and other familiar friends, catecholamines and phosphodiesterase inhibitors became established before formal long-term outcomes testing of drugs became mandatory, so proof of benefit and safety profiles were never properly characterised. The treatment

*Correspondence: m.singer@ucl.ac.uk

Bloomsbury Institute of Intensive Care Medicine, University College London, Cruciform Building, Gower Street, London WC1E 6BT, UK provided what was claimed on the package insert (an inotropic action) and we looked no further.

Dobutamine was key to Shoemaker and colleagues' concept of supranormal circulatory optimisation of highrisk surgical patients [4], and, to be fair, was an integral part of a successful optimisation protocol after cardiac surgery that targeted mixed venous oxygen saturation and lactate [5]. A perioperative goal-driven approach may thus be more efficacious - and safer - than empiric administration, but this should not be freely extrapolated to other conditions. For example, the Shoemaker approach was forcefully marketed towards managing established severe sepsis and shock, yet, when formally challenged, its use proved deleterious in a dose-dependent manner [6]. While this deterred intensivists from using high doses to achieve targeted values of oxygen delivery and consumption, the general use of catecholamines remains unabated.

A further fillip came from Rivers and colleagues' Early Goal-Directed Therapy strategy for patients presenting with severe sepsis [7]; this study led to dobutamine becoming enshrined in the Surviving Sepsis Campaign guidelines [8], albeit based on a mere 18 patients whose outcomes remain unknown. Recent studies in shocked patients showed equivalent mortality rates when randomised to epinephrine or norepinephrine plus dobutamine $[9,10]$. But are these equally good or equally bad? A wealth of animal and cell studies show a wide range of covert harm from catecholamines; for instance, stimulation of bacterial growth yet concurrent immunosuppression, decreased metabolic efficiency, potent thrombogenicity, tissue hypoxia through excessive microvascular vasoconstriction, and myocardial damage [11]. A retrospective analysis of catecholamine use in a septic shock trial revealed increased dose-related mortality with progressive increases in blood pressure [12].

What options do we have? Currently, these options are relatively limited and further extensive study is required before any can be strongly endorsed. Phosphodiesterase inhibitors, like catecholamines, have similar detrimental outcomes, and this appears to be a class effect $[13,14]$. Vasopressin or synthetic analogues such as terlipressin may be potentially superior vasopressors, while levosimendan offers a viable alternative in low cardiac output 
states by increasing contractility through a variety of mechanisms including increased cardiomyocyte calcium sensitisation and peripheral vasodilatation, although not at the expense of a large increase in cardiac work.

New agents in development such as myosin activators and the $\mathrm{Na}^{+} / \mathrm{K}^{+}$-ATPase antagonists show promise, as does the concept of metabolic modulation - encouraging the mitochondria to use glucose preferentially over fatty acid, thereby generating ATP more efficiently in terms of oxygen consumption [15]. This modulation can be achieved by blocking fatty acid entry into mitochondria (for example, using a carnitine palmitoyl transferase inhibitor such as perhexiline) or by enhancing utilisation of glucose through a high-dose glucose-insulin-potassium infusion. This strategy has become the treatment of choice for life-threatening overdoses of calcium channel blockers and some antidepressants. While an immediate, end-of-the-needle effect is not seen, the treatment still merits exploration in other critically ill patient groups.

In the short term, we can also focus on catecholamine sparing. What blood pressure should we aim for in an individual patient? Guidelines target populations not individuals. If perfusion appears adequate at a mean of, say, 55 to $60 \mathrm{mmHg}$, is there any point in driving it higher? Furthermore, does the patient need heavy sedation, a frequent side effect of which is hypotension? The crucial recognition of iatrogenic harm through blood transfusion, high tidal volumes, excess sedation, and so forth, can (and should) be readily extended to catecholamine use.

\section{Competing interests}

The authors declare that they have no competing interests.

\section{Acknowledgements}

The present work was undertaken at University College London Hospitals/ University College London, which receives a proportion of its funding from the funding scheme of the UK Department of Health's National Institute for Health Research Biomedical Research Centre.

Published: 8 August 2011

\section{References}

1. Shahin J, deVarennes B, Wing Tse C, Amarica DA, Dial S: The relationship between inotrope exposure, six-hour physiological variables, and hospital mortality and renal dysfunction in patients undergoing cardiac surgery. Crit Care 2011, 15:R162.
2. Fellahi JL, Parienti JJ, Hanouz JL, Plaud B, Riou B, Ouattara A: Perioperative use of dobutamine in cardiac surgery and adverse cardiac outcome: propensity-adjusted analyses. Anesthesiology 2008, 108:979-987.

3. Butterworth JF IV, Legault C, Royster RL, Hammon JW: Factors that predict the use of positive inotropic drug support after cardiac valve surgery. Anesth Analg 1998, 86:461-467.

4. Shoemaker WC, Appel PL, Kram HB, Waxman K, Lee TS: Prospective trial of supranormal values of survivors as therapeutic goals in high-risk surgical patients. Chest 1988, 94:1176-1186.

5. Polonen P, Ruokonen E, Hippelainen M, Poyhonen M, Takala J: A prospective, randomized study of goal-oriented hemodynamic therapy in cardiac surgical patients. Anesth Analg 2000, 90:1052-1059.

6. Hayes MA, Timmins AC, Yau EH, Palazzo M, Hinds CJ, Watson D: Elevation of systemic oxygen delivery in the treatment of critically ill patients. NEng/ J Med 1994, 330:1717-1722.

7. Rivers E, Nguyen B, Havstad S, Ressler J, Muzzin A, Knoblich B, Peterson E, Tomlanovich M; Early Goal-directed Therapy Collaborative Group: Early goaldirected therapy in the treatment of severe sepsis and septic shock. N Engl J Med 2001, 345:1368-1377.

8. Dellinger RP, Levy MM, Carlet JM, Bion J, Parker MM, Jaeschke R, Reinhart K, Angus DC, Brun-Buisson C, Beale R, Calandra T, Dhainaut JF, Gerlach H, Harvey M, Marini JJ, Marshall J, Ranieri M, Ramsay G, Sevransky J, Thompson BT, Townsend S, Vender JS, Zimmerman JL, Vincent JL, et al: Surviving Sepsis Campaign: international guidelines for management of severe sepsis and septic shock: 2008. Crit Care Med 2008, 36:296-327.

9. Annane D, Vignon P, Renault A, Bollaert PE, Charpentier C, Martin C, Troche G Ricard JD, Nitenberg G, Papazian L, Azoulay E, Bellissant E: Norepinephrine plus dobutamine versus epinephrine alone for management of septic shock: a randomised trial. Lancet 2007, 370:676-684.

10. Myburgh JA, Higgins A, Jovanovska A, Lipman J, Ramakrishnan N, Santamaria $\mathrm{J}$ : A comparison of epinephrine and norepinephrine in critically ill patients. Intensive Care Med 2008, 34:2226-2234.

11. Singer M: Catecholamine treatment for shock - equally good or bad? Lancet 2007, 370:636-637.

12. Dunser M, Ruokonen E, Pettila V, Ulmer H, Torgersen C, Schmittinger C, Jakob S, Takala J: Association of arterial blood pressure and vasopressor load with septic shock mortality: a post hoc analysis of a multicenter trial. Crit Care 2009, 13:R181.

13. Cuffe MS, Califf RM, Adams KF, Benza R, Bourge R, Colucci WS, Massie BM, O'Connor CM, Pina I, Quigg R, Silver MA, Gheorghiade M: Short-term intravenous milrinone for acute exacerbation of chronic heart failure: a randomized controlled trial. JAMA 2002, 287:1541-1547.

14. Cohn JN, Goldstein SO, Greenberg BH, Lorell BH, Bourge RC, Jaski BE, Gottlieb SO, McGrew F, DeMets DL, White BG: A dose-dependent increase in mortality with vesnarinone among patients with severe heart failure. Vesnarinone Trial Investigators. N Engl J Med 1998, 339:1810-1816.

15. Hasenfuss G, Teerlink TR: Cardiac inotropes: current agents and future directions. Eur Heart J 2011, in press. [Epub ahead of print]

doi:10.1186/cc10311

Cite this article as: Singer M, Brealey D: Another nail in the hammer's coffin? Critical Care 2011, 15:179. 